\title{
PENGEMBANGAN LEMBAR KEGIATAN MAHASISWA MATEMATIKA DASAR
}

\author{
Susanah \\ Pendidikan Matematika, FMIPA, Universitas Negeri Surabaya \\ susanah@unesa.ac.id
}

\begin{abstract}
Abstrak
Penelitian ini bertujuan untuk mendeskripsikan proses pengembangan dan menghasilkan Lembar Kegiatan Mahasiswa (LKM) mata kuliah Matematika Dasar untuk pembelajaran yang valid, praktis dan efektif. Penelitian ini dilaksanakan di Program Studi Pendidikan Biologi angkatan 2018 tahun akademik 2018/2019. Proses pengembangan LKM ini dilaksanakan dengan mengikuti tahapan pengembangan hasil modifikasi model pengembangan yang dikemukakan oleh Plomp, yang disebut model umum pemecahan masalah pendidikan (The general model of educational problem solving). Model ini terdiri dari lima fase, yakni: (a) Investigasi Awal, (b) Desain (Design), (c) Realisasi/Konstruksi (Realization/Construction), (d) Pengujian, Evaluasi, dan Revisi (Test, Evaluation, and Revision), dan (e) Implementasi (Implementation). Pada penelitian ini fase 5 (Implementasi) tidak dilaksanakan. LKM yang dihasilkan sebanyak 7 untuk perkuliahan selama satu semester. LKM yang dihasilkan memenuhi kriteria sangat valid dan praktis didasarkan simpulan dua orang ahli yang menyatakan bahwa LKM tersebut dapat digunakan dengan sedikit revisi pada redaksi dan sajian materi. Berdasarkan hasil pengamatan proses pembelajaran oleh seorang pengamat pembelajaran Matematika Dasar dapat terlaksana dengan baik. LKM yang dihasilkan juga dinyatakan efektif karena mahasiswa yang memprogram mata kuliah Matematika Dasar memperoleh nilai minimal B-, mahasiswa juga memberikan respon positip terhadap aspek yang ditanyakan.
\end{abstract}

Kata Kunci: Pengembangan LKM, Matematika Dasar.

Abstract

This study aims to describe the development process of designing students' worksheet on Course Matematika Dasar (Basic Mathematics) which is valid, can be practically used, and effective. The developed worksheet was tested in Biology department and involves the Biology Education Students Class of 2018 at academic year 2018/2019. The process is based on the modified method of Plomp's developmental steps, which is called the general model of educational problem solving). The model consists of five phases: (a) preliminary investigation, (b) Design, (c) Realization/Construction, (d) Test, Evaluation, and Revision, and (e) Implementation. We did not yet do the last phase. There are seven developed worksheets which was used during the course. The worksheet is valid and can be practically used. This is concluded from the statements of two experts who said that the worksheet can be used with minor revision on the redaction and material arrangement. Based on observation of the learning process by observers, basic mathematical instruction was done well. The developed worksheets are regarded as effective because students minimum mark is B-, students also respond positively to the proposed aspects.

Keywords: Worksheet development, Basic Mathematics.

\section{PENDAHULUAN}

Unesa merupakan salah satu Perguruan Tinggi Negeri yang menciptakan calon pendidik. Oleh karena itu Unesa perlu menyiapkan langkah-langkah atau melaksanakan program-program yang unggul guna menuju pada suatu paradigma untuk menjadikan pengajaran (teaching) sebagai tonggak dan sarana meningkatkan kualitas pendidikan dan pengajaran di kampus. Sebagaimana terlihat pada milestones Unesa 2016-2035 disebutkan bahwa sejak tahun 2016 Unesa telah mencanangkan untuk mewujudkan recognized national teaching university, yaitu terwujudnya UNESA sebagai universitas terpandang secara nasional dalam bidang pengajaran. (Pedoman penelitian Universitas Surabaya, 2018).

Untuk mendukung terwujudnya universitas yang terpandang tersebut salah satunya adalah mewujudkan calon pendidik yang berkualitas. Calon pendidik yang dimaksud dipersiapkan di Program Studi Pendidikan yang ada di Unesa. Sejak tahun 2015 ada perubahan kurikulum tentang mata kuliah dasar bersama yang harus ditempuh mahasiswa pendidikan di Unesa. Salah satu mata kuliah tersebut adalah mata kuliah Matematika 
Dasar. Matematika Dasar merupakan matakuliah yang memuat materi matematika yang ada di SMA dan diulas kembali lebih mendalam di Prodi Pendidikan di Unesa, materi tersebut antara lain meliputi: (1) persamaan dan pertidaksamaan, (2) fungsi, (3) teori peluang, (4) matriks, (5) limit fungsi, (6) turunan dan diferensial, (7) intergral dan aplikasikasinya (Buku Pedoman Unesa, 2015).

Berdasarkan pengalaman Peneliti saat mengajar mata kuliah Matematika Dasar kemampuan awal mahasiswa tentang matematika yang diterima di SMA dan yang sederajat masih rendah. Hal ini ditunjukkan dari hasil tes materi prasyarat yang diperoleh masih di bawah 60 dari skor 100. Mahasiswa masih mengalami kesulitan dan kesalahan dalam memahami materi yang terdapat pada mata kuliah Matematika Dasar saat mereka mengikuti perkuliahan. LKM untuk matakuliah Matematika Dasar belum tersedia dalam proses pembelajaran.

Untuk memperbaiki dan mengatasi permasalahan dalam mata kuliah Matematika Dasar, Peneliti merancang dan menggunakan LKM setiap proses perkuliahan. LKM merupakan suatu bahan ajar cetak berupa lembaran berisi tugas yang di dalamnya berisi petunjuk, langkah-langkah untuk menyelesaikan tugas. LKM dapat berupa panduan untuk latihan pengembangan aspek kognitif maupun panduan untuk pengembangan semua aspek pembelajaran dalam bentuk panduan eksperimen dan demonstrasi (Trianto, 2007). LKM adalah lembaran-lembaran yang berisi tugas yang harus dikerjakan oleh mahasiswa. LKM bukan kumpulan soalsoal, akan tetapi tahapan-tahapan kegiatan yang dilakukan mahasiswa untuk membangun pengetahuanya. LKM biasanya berisi petunjuk, langkahlangkah untuk menyelesaikan suatu tugas. LKM bahkan dapat berupa rangkuman materi ajar yang sudah dikemas sedemikian rupa, sehingga mahasiswa diharapkan dapat mempelajari materi ajar tersebut secara mandiri dan menyelesaikan tugas yang diberikan dosen. Dalam LKM, mahasiswa akan mendapatkan ringkasan materi, dan tugas yang berkaitan dengan materi. Selain itu, mahasiswa juga dapat menemukan arahan yang terstruktur untuk memahami materi yang diberikan (Prastowo, 2011). LKM merupakan salah satu sarana untuk membantu dan mempermudah dalam kegiatan pembelajaran sehingga akan terbentuk interaksi yang efektif antara peserta didik dengan pendidik, dan dapat meningkatkan aktivitas peserta didik dalam peningkatan prestasi belajar. Tugas-tugas yang diberikan kepada peserta didik dapat berupa teori atau praktek. (Dinas Pendidikan Nasional, 2006).

Tujuan penyusunan LKM antara lain: 1) menyajikan bahan ajar yang memudahkan mahasiswa untuk berinteraksi dengan materi yang diberikan; 2) menyajikan tugas-tugas yang menjadikan mahasiswa memperoleh keterampilan berpikir dan olah tangan; 3) melatih kemandirian belajar mahasiswa sehingga bisa memperoleh pembelajaran yang bermakna; 4) memudahkan dosen dalam memberikan tugas kepada mahasiswa (Prastowo, 2011). LKM yang dikembangkan dalam penelitian ini termasuk LKM terbimbing.

Penelitian ini bertujuan untuk mengembangkan LKM mata kuliah Matematika Dasar untuk pembelajaran di Prodi Pendidikan yang valid, praktis dan efektif. Kevalidan LKM ditentukan oleh hasil validasi para ahli. Kepraktisan LKM ditentukan oleh hasil penilaian oleh praktisi dan fisibilitas LKM jika diterapkan dalam pembelajaran, keefektifan LKM ditentukan oleh hasil belajar, kemampuan dosen untuk melaksanakan proses pembelajaran dan respon mahasiswa terhadap proses pembelajaran mata kuliah Matematika Dasar.

\section{METODE}

Jenis penelitian ini termasuk developmental research. Subjek penelitian ini adalah satu dosen pengampu mata kuliah Matematika Dasar dan mahasiswa Prodi Pendidikan Biologi angkatan 2018 yang memprogram mata kuliah Matematika Dasar pada semester gasal tahun akademik 2018/2019 FMIPA Unesa.

Langkah-langkah yang Peneliti lakukan dengan memperhatikan tiga aspek kualitas produk dari Nieveen serta mengikuti tahapan pengembangan yang diadaptasi dari Plomp yaitu 1) investigasi awal, 2) desain, 3) relasi, 4) Pengujian, Evaluasi, dan revisi, serta 5) implementasi. Namun, penelitian ini merupakan penelitian pengembangan, maka fase 5 tidak dilakukan. Pengumpulan data dalam penelitian ini dilakukan dengan menggunakan beberapa instrumen, yaitu: (1) lembar validasi instrumen, (2) LKM, (3) lembar pengamatan pembelajaran, (4) soal ujian tengah semester, dan (5) angket respon mahasiswa.

Untuk menentukan valid tidaknya LKM, dilakukan analisis data terhadap hasil validasi LKM oleh dua ahli. Kriteria yang digunakan untuk memutuskan bahwa LKM dikatakan memenuhi aspek validitas jika hasil validasi kedua validator menyatakan kriteria valid atau sangat valid dan LKM dapat digunakan dengan revisi kecil. Untuk menentukan praktis tidaknya LKM, dilakukan analisis data terhadap hasil pengamatan proses pembelajaran yang menggunakan LKM oleh seorang pengamat. Menentukan kategori keterlaksanaan setiap aspek atau keseluruhan aspek dengan kategori keterlaksanaan yang ditetapkan, sebagai berikut. 


$$
\begin{aligned}
& 3<M \leq 4 \\
& 2<M \leq 3 \\
& 1<M \leq 2 \\
& M=1
\end{aligned}
$$$$
\text { sangat baik }
$$$$
\text { baik }
$$$$
\text { kurang baik }
$$$$
\text { sangat kurang baik }
$$

$\mathrm{M}$ : rerata hasil pengamatan

Kriteria yang digunakan untuk memutuskan bahwa LKM dikatakan memenuhi aspek kepraktisan jika hasil pengamatan proses pembelajaran dengan menggunakan LKM kriteria baik atau sangat baik. Untuk menentukan efektif tidaknya LKM, ditentukan oleh hasil belajar mahasiswa dalam pembelajaran Matematika Dasar dikatakan baik jika minimal 75\% mahasiswa memperoleh minimal nilai B-. Mahasiswa memiliki respon positip adalah jika minimal 50\% mahasiswa memberikan respon positip terhadap aspek yang ditanyakan.

\section{HASIL DAN PEMBAHASAN}

\section{Proses Pengembangan}

Proses pengembangan LKM matakuliah Matematika Dasar pada fase Investigasi Awal ditemukan informasi LKM untuk pembelajaran Matematika Dasar semester gasal 2018/2019 belum tersedia, perlunya dikembangkan LKM untuk pembelajaran Matematika Dasar. Pada fase desain dirancang LKM dan soal UTS pembelajaran Matematika Dasar untuk 15 kali tatap muka. Selain itu, pada fase ini disusun pula instrumen penelitian yang berupa: lembar pengamatan keterlaksanaan proses pembelajaran, lembar angket respon mahasiswa, serta lembar validasi instrumen. Pada fase realisasi/konstruksi dikembangkan desain versi pertama dari LKM, soal UTS, lembar pengamatan keterlaksanaan proses pembelajaran, lembar angket respon mahasiswa, serta lembar validasi instrumen penelitian yang disebut prototipe I. Pada Fase Pengujian, Evaluasi, dan Revisi semua LKM dilvalidasi oleh dua orang ahli, dan kedua validator menyatakan valid dengan

\begin{tabular}{|c|c|c|c|c|c|c|}
\hline \multirow{3}{*}{$\begin{array}{c}\text { LKM } \\
1\end{array}$} & \multirow{3}{*}{$\begin{array}{c}\text { Materi } \\
\text { Persamaan } \\
\text { dan } \\
\text { Pertidaksa } \\
\text { maan }\end{array}$} & \multicolumn{4}{|c|}{ Hasil Penilaian } & \multirow{3}{*}{$\begin{array}{c}\begin{array}{c}\text { Tindak } \\
\text { Lanjut }\end{array} \\
\begin{array}{c}\text { Revisi dan } \\
\text { diskusi dengan } \\
\text { validator }\end{array}\end{array}$} \\
\hline & & \multicolumn{2}{|c|}{ Validator 1} & \multicolumn{2}{|c|}{$\begin{array}{c}\text { Validator } \\
2\end{array}$} & \\
\hline & & $\mathrm{CV}$ & DS & $\mathrm{V}$ & DS & \\
\hline 2 & Fungsi & $\mathrm{V}$ & DS & $\mathrm{V}$ & DS & $\begin{array}{c}\text { Revisi dan } \\
\text { diskusi dengan } \\
\text { validator }\end{array}$ \\
\hline 3 & Peluang & $\mathrm{V}$ & DS & $\mathrm{V}$ & DS & $\begin{array}{c}\text { Revisi dan } \\
\text { diskusi dengan } \\
\text { validator }\end{array}$ \\
\hline
\end{tabular}
sedikit revisi. Adapun hasil validasi oleh validator dapat disajikan masing-masing sebagai berikut.

Tabel 1. Validasi LKM

\begin{tabular}{|c|c|c|c|c|c|c|}
\hline \multirow{2}{*}{ LKM } & Materi & \multicolumn{3}{|c|}{ Hasil Penilaian } & \multirow{2}{*}{$\begin{array}{c}\text { Tindak } \\
\text { Validator 1 }\end{array}$} & \multicolumn{2}{|c|}{$\begin{array}{c}\text { Validator } \\
\mathbf{2}\end{array}$} & \multicolumn{2}{|c|}{\begin{tabular}{c} 
Lanjut \\
\cline { 3 - 6 }
\end{tabular}} & Matriks & CV & DS & V & DS & $\begin{array}{c}\text { Revisi dan } \\
\text { diskusi dengan } \\
\text { validator }\end{array}$ \\
\hline 5 & Limit & V & DS & V & DS & $\begin{array}{c}\text { Revisi dan } \\
\text { diskusi dengan } \\
\text { validator }\end{array}$ \\
\hline 6 & $\begin{array}{c}\text { Fungsi } \\
\text { danan } \\
\text { Diferensia } \\
1\end{array}$ & V & DS & V & DS & $\begin{array}{c}\text { Revisi dan } \\
\text { diskusi dengan } \\
\text { validator }\end{array}$ \\
\hline 7 & $\begin{array}{c}\text { Integral } \\
\text { dan } \\
\text { Aplikasiny } \\
\text { a }\end{array}$ & V & DS & V & DS & $\begin{array}{c}\text { Revisi dan } \\
\text { diskusi dengan } \\
\text { validator }\end{array}$ \\
\hline
\end{tabular}

\section{Keterangan:}

LKM : Lembar Kegiatan Mahasiswa

CV : cukup valid

DS : dapat digunakan dengan sedikit revisi

V : valid

Berikut adalah proses validasi LKM 1 sampai dengan

\begin{tabular}{|c|c|c|c|c|}
\hline LKM & $\begin{array}{c}\text { Sebelum } \\
\text { Revisi }\end{array}$ & $\begin{array}{l}\text { Masukan } \\
\text { Valdator 1 }\end{array}$ & $\begin{array}{c}\text { Masukan } \\
\text { Valdator } 2\end{array}$ & $\begin{array}{l}\text { Setelah } \\
\text { Direvisi }\end{array}$ \\
\hline 1 & $\begin{array}{l}\text { Soal no. } 1 \\
\text { Jika } \\
\text { peubah } \\
\text { pada } \\
\text { himpunan } \\
\text { Bilangan } \\
\text { Real. } \\
\text { Soal no. 4c } \\
\text { tertulis } \\
\text { kalikan } \\
\text { pembilang } \\
\text { dan } \\
\text { penyebut }\end{array}$ & $\begin{array}{l}\text { Soal no. 1 Jika } \\
\boldsymbol{x} \quad \text { anggota } \\
\text { himpunan } \\
\text { Bilangan } \\
\text { Real. } \\
\text { Soal no. 4c } \\
\text { tertulis } \\
\text { kalikan } \\
\text { pembilang } \\
\text { kuadrat } \\
\text { penyebutnya. }\end{array}$ & $\begin{array}{l}\text { Jika } x \text { peubah } \\
\text { pada } \\
\text { himpunan } \\
\text { bilangan real. } \\
\text { Tidak ada. }\end{array}$ & $\begin{array}{l}\text { Jika } \\
\text { anggota } \\
\text { himpunan } \\
\text { bilangan } \\
\text { real. } \\
\text { Kalikan } \\
\text { pembilang } \\
\text { kuadrat } \\
\text { penyebutnya }\end{array}$ \\
\hline 2 & $\begin{array}{l}\text { Soal no. } 3 \\
\text { belum ada } \\
\text { tutunan } \\
\text { pada } \\
\text { jawaban. } \\
\text { Soal no. } 4 \\
\text { tertulis } \\
\text { gambar }\end{array}$ & $\begin{array}{l}\text { Tidak ada. } \\
\text { Soal no. 4b } \\
\text { tertulis } \\
\text { gambarlah }\end{array}$ & $\begin{array}{l}\text { Soal no. } 3 \\
\text { diberi } \\
\text { masukan } \\
\text { diberi tutunan } \\
\text { pada jawaban. } \\
\text { Tidak ada }\end{array}$ & $\begin{array}{l}\text { Soal no. } 3 \\
\text { diberi } \\
\text { tutunan pada } \\
\text { jawaban } \\
\text { Soal no. } 4 \\
\text { tertulis } \\
\text { gambarlah }\end{array}$ \\
\hline 3 & $\begin{array}{l}\text { Jika satu } \\
\text { orang } \\
\text { dipilih } \\
\text { secara } \\
\text { acak, } \\
\text { berapakah } \\
\text { peluang } \\
\text { orang yang } \\
\text { terpilih } \\
\text { tersebut } \\
\text { berjenis } \\
\text { kelamin } \\
\text { LAKI, dari } \\
\text { seorang } \\
\text { PEKERJA } \\
\text { ? }\end{array}$ & $\begin{array}{l}\text { Jika satu } \\
\text { orang dipilih } \\
\text { secara acak, } \\
\text { berapakah } \\
\text { peluang yang } \\
\text { terpilih adalah } \\
\text { pekerja yang } \\
\text { berjenis } \\
\text { kelamin } \\
\text { LAKI? }\end{array}$ & $\begin{array}{l}\text { Jika satu } \\
\text { orang dipilih } \\
\text { secara acak, } \\
\text { berapakah } \\
\text { peluang orang } \\
\text { yang terpilih } \\
\text { tersebut } \\
\text { berjenis } \\
\text { kelamin } \\
\text { LAKI-LAKI, } \\
\text { dari seorang } \\
\text { PEKERJA? }\end{array}$ & $\begin{array}{l}\text { Jika satu } \\
\text { orang dipilih } \\
\text { secara acak, } \\
\text { berapakah } \\
\text { peluang } \\
\text { yang terpilih } \\
\text { adalah } \\
\text { pekerja yang } \\
\text { berjenis } \\
\text { kelamin } \\
\text { LAKI? }\end{array}$ \\
\hline 4 & $\begin{array}{l}\text { Bentuklah } \\
\text { sistem } \\
\text { persamaan } \\
\text { di atas } \\
\text { dalam } \\
\text { perkalian } 3 \\
\end{array}$ & $\begin{array}{l}\text { Bentuklah } \\
\text { sistem } \\
\text { persamaan di } \\
\text { atas dalam } \\
\text { perkalian } \\
\text { matriks, misal }\end{array}$ & Tidak ada & $\begin{array}{l}\text { Bentuklah } \\
\text { sistem } \\
\text { persamaan } \\
\text { di atas dalam } \\
\text { perkalian } \\
\text { matriks, }\end{array}$ \\
\hline
\end{tabular}
LKM 7 dari dua validator dan hasil revisinya yang telah dilakukan oleh Peneliti.

Tabel 2. Proses Revisi LKM 


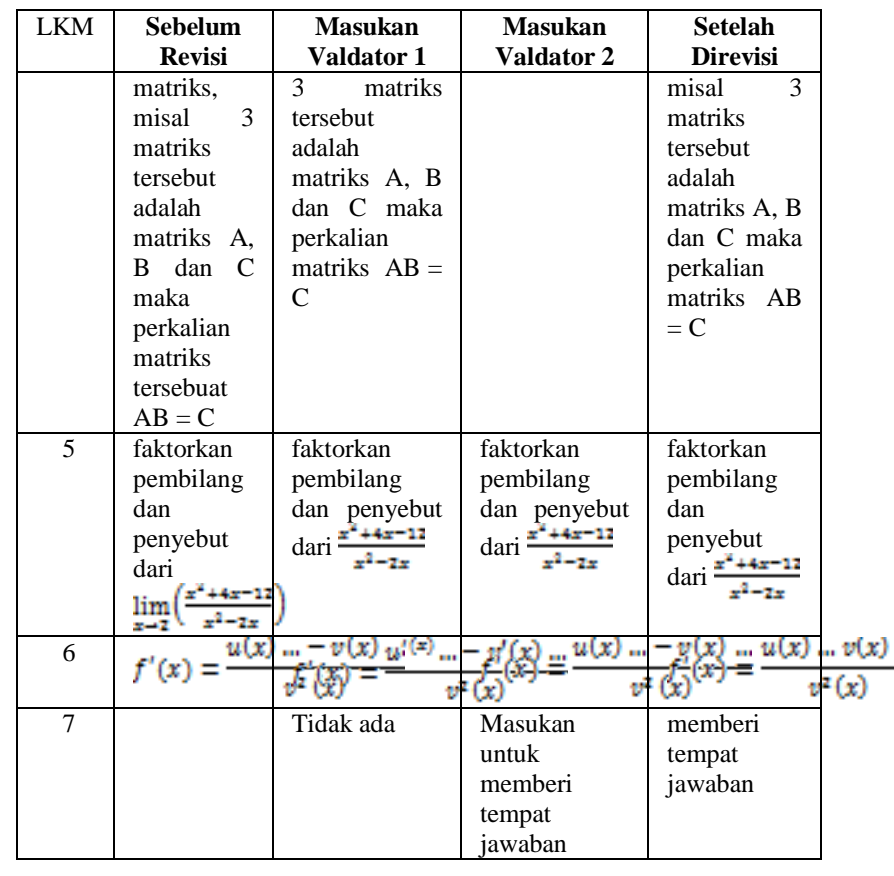

Pengamatan keterlaksanaan proses pembelajaran untuk tujuh kali pertemuan (saat penggunaan LKM dalam pembelajaran) oleh pengamat rata-rata skor pada kegiatan pendahuluan 3,95, kegiatan inti 3,89 dan kegiatan penutup 3,86 sehingga proses pembelajaran untuk tujuh kali pertemuan dinyatakan sangat baik.

Efektifitas LKM matakuliah Matematika Dasar, dilakukan berdasarkan data hasil belajar mahasiswa menggunakan empat komponen, yaitu; nilai partisipasi mahasiswa $(=\mathrm{P})$, nilai tugas $(=\mathrm{T})$, hasil ulangan tengah semester (=UTS) dan hasil ujian akhir semester (=US), sedangkann ilai akhir mahasiswa (=NA) ditentukan dengan menggunakan rumus

$$
\mathrm{NA}=\frac{2 \times \mathrm{P}+3 \times \mathrm{T}+2 \times \mathrm{UTS}+3 \times \mathrm{US}}{10}
$$

Dari 28 mahasiswa yang memprogram mata kuliah matematika dasar dinyatakan baik karena persentase mahasiswa yang memperoleh nilai minimum Bsebanyak $78,57 \%$ dengan rincian 2 orang $(7,14 \%)$ mendapatkan nilai C, 4 orang $(14,29 \%)$ mendapatkan nilai $\mathrm{C}+, 3$ orang $(10,71 \%)$ mendapatkan nilai B-, 9 orang $(32,14 \%)$ mendapatkan nilai B, 4 orang $(14,29 \%)$ mendapatkan nilai $\mathrm{B}+, 2$ orang $(7,14 \%)$ mendapatkan nilai A-, dan 3 orang $(10,71 \%)$ mendapatkan nilai A.

Pada akhir pertemuan kuliah, para mahasiswa diminta untuk mengisi angket respon mahasiswa selama mengikuti perkuliahan Matematika Dasar. Butir angket yang diberikan terdiri atas butir yang favourable dan butir yang unfavourable. Berdasarkan pengolahan hasil angket dinyatakan bahwa mahasiswa yang memprogram matakuliah Matematika Dasar memiliki respon positip, karena lebih dari 50\% mahasiswa memberikan respon positip terhadap $100 \%$ aspek yang ditanyakan.

\section{Hasil Pengembangan}

Hasil pengembangan LKM yang telah dihasilkan adalah a) Hasil investigasi berdasarkan kurikulum, diskripsi matakuliah dan kebutuhan mahasiswa materi yang di sajikan dalam LKM adalah; (1) persamaan dan pertidaksamaan, (2) fungsi, (3) teori peluang, (4) matriks, (5) limit fungsi, (6) turunan dan diferensial, (7) intergral dan aplikasikasinya, b) LKM Matematika Dasar yang dikembangkan di dapat 7 LKM. LKM 1 tentang persamaan dan pertidaksamaan, LKM 2 tentang fungsi, LKM 3 tentang teori peluang, LKM 4 tentang matriks, LKM 5 tentang limit fungsi, LKM 6 tentang turunan dan diferensial dan LKM 7 tentang integral dan aplikasinya. Berdasarkan hasil validasi dua orang ahli maka dihasilkan LKM Matematika Dasar memenuhi kriteria valid karena kedua validator menyatakan LKM yang dibuat valid sedangkan hasil validator. LKM Matematika Dasar yang dikembangkan memenuhi kriteria praktis. Hal ini didasarkan simpulan dua orang ahli yang menyatakan bahwa LKM tersebut dapat digunakan dengan sedikit revisi pada redaksi dan sajian materi. Selain itu, berdasarkan hasil pengamatan seorang pengamat, dapat dinyatakan bahwa proses pelaksanaan pembelajaran Matematika Dasar yang menggunakan LKM dapat terlaksana dengan sangat baik. Hal ini karena hasil penilaian pengamat proses pembelajaran Matematika Dasar yang menggunakan LKM 1 sampai dengan LKM 7 pada kegiatan pendahuluan, kegiatan Inti dan penutup mendapat skor di atas 3,5 dari skor 4 . LKM Matematika Dasar yang dikembangkan memenuhi kriteria efektif, karena $75 \%$ mahasiswa yang memprogram mata kuliah Matematika Dasar memperolah nilai minimum B-. Berdasarkan rekap angket respos yang diberikan $100 \%$ mahasiswa memberikan respon positip terhadap 100\% aspek yang ditanyakan.

\section{PENUTUP}

\section{Simpulan}

Berdasarkan hasil analisis data dan pembahasan yang telah diuraikan sebelumnya, peneliti dapat menyimpulkan beberapa hal sebagai berikut.

1. Proses pengembangan LKM mata kuliah Matematika Dasar untuk pembelajaran dilakukan investigasi berdasarkan kurikulum, diskripsi matakuliah dan kebutuhan mahasiswa angkatan tahun 2018 adalah materi yang di sajikan dalam LKM. Berdasarkan investigasi dihasilkan 7 LKM Matematika Dasar selanjutnya diberikan kepada 2 orang ahli untuk di validasi. Berdasarkan hasil validasi 2 orang ahli LKM 
Matematika Dasar yang dikembangkan dinyatakan pada kriteria valid. LKM Matematika Dasar yang dikembangkan memenuhi kriteria praktis, karena didasarkan simpulan dua orang ahli yang menyatakan LKM tersebut dapat digunakan dengan sedikit revisi. Selain itu, berdasarkan hasil pengamatan seorang pengamat, dapat dinyatakan bahwa pembelajaran Matematika Dasar yang menggunakan LKM dapat terlaksana dengan baik. LKM Matematika Dasar yang dikembangkan memenuhi kriteria efektif, karena $75 \%$ mahasiswa yang memprogram mata kuliah Matematika Dasar memperoleh nilai minimum B-, dan $100 \%$ mahasiswa memberikan respon positip terhadap 100\% aspek yang ditanyakan.

2. Hasil pengembangan LKM mata kuliah Matematika Dasar untuk pembelajaran diperoleh LKM 1 tentang persamaan dan pertidaksamaan, LKM 2 tentang fungsi, LKM 3 tentang teori peluang, LKM 4 tentang matriks, LKM 5 tentang limit fungsi, LKM 6 tentang turunan dan diferensial dan LKM 7 tentang integral dan aplikasinya.

\section{Saran}

Berdasarkan hasil penelitian tersebut, peneliti memberikan saran kepada para dosen Pembina mata kuliah Matematika Dasar di Prodi Pendidikan, hendaknya berusaha menggunakan LKM dalam pembelajaran untuk membantu proses pembelajaran. Bahkan LKM yang telah peneliti kembangkan, bisa digunakan dalam pembelajaran karena LKM telah memenuhi kriteria valid, praktis, dan efektif.

\section{UCAPAN TERIMA KASIH}

Peneliti mengucapkan banyak terima kasih kepada pihak FMIPA Unesa yang telah memfasilitasi penelitian ini, Selain itu juga peneliti ucapkan terima kasih kepada Dr. Masriyah, M.Pd., Evangelista Lus W.P., S.Pd. M.Sc. sebagai validator, dan Rudianto Artiono, M.Si., sebagai pengamat.

\section{DAFTAR PUSTAKA}

Abadi dkk. 2016. Matematika Dasar. Surabaya: Unipres Unesa.

Buku Pedoman Universitas Negeri Surabaya (Unesa). 2015/2016. Matematika dan Ilmu Pengetahuan Alam.

Depdiknas.2006. Standar Isi Kurikulum Tingkat Satuan Pendidikan. Jakarta: Departemen Pendidikan Nasional.

Nieveen, Nienke. 1999. Prototyping to Reach Product Quality. In Jan Van den Akker, R.M. Branch, K. Gustafson, N. Nieveen, \& Tj. Design Approach in
Tools in Education and Training. 125-135. Dordrecht, The Nederlands: Kluwer Academic Publishers.

Partmore, Mark and Seager, Brian. 2007. Mathematics (revise GCSE Maths).

Prastowo, Andi. 2011. Panduan Membuat Bahan Ajar Inovatif. Yogyakarka: Diva Press.

Plomp, Tjeerd., 1997. Educational and Training System Design. Enschede. The Netherlands: University of Twente.

Purcel. Edwin, J., \& Varberg, Dale, 1987. Calculus with Analytic Geometry, Englewood Cliffs: Prentice-Hall, Inc.

Sulaiman, Raden. 2010. Kalkulus Integral. Surabaya: Unipres Unesa.

Trianto. 2010. Mendesain Model Pembelajaran InovatifProgresif. Jakarta : Penerbit Kencana. 
Susanah: Pengembangan Lembar Kegiatan Mahasiswa Matematika Dasar 